九州大学学術情報リポジトリ

Kyushu University Institutional Repository

Loss of Eggs Attached to the Pleopods in Metanephrops thomsoni (Bate, 1888) (Crustacea, Decapoda, Nephropidae)

Matsuura, Shuhe i

Department of Fisheries, Faculty of Agriculture, Kyushu University

Hamasaki, Katsuyuki

Department of Fisheries, Faculty of Agriculture, Kyushu University

https://doi.org/10.5109/23860

出版情報 : 九州大学大学院農学研究院紀要. 31 (4), pp.405-410，1987-03-31. Kyushu University バージョン：

権利関係 : 


\title{
Loss of Eggs Attached to the Pleopods in Metanephrops thomsoni (Bate, 1888) (Crustacea, Decapoda, Nephropidae)
}

\author{
Shuhei Matsuura and Katsuyuki Hamasaki* \\ Department of Fisheries, Faculty of Agriculture, \\ Kyushu University 46-04, Hakozaki, Fukuoka 812
}

(Received December IO, 1986)

\begin{abstract}
The number of eggs attached to the pleopods of Metanephrops thomsoni from the East China Sea was studied in order to evaluate the fecundity. The stages of embryonic development of the eggs incubated on the pleopods were classified into four phases, and then the relationship between the carapace length and the number of eggs in each phase was examined. Analyses of regression equations indicated that an egg loss of $46 \%$ at least occurred during the course of embryonic development. Consequently, it was suggested that the regression equation for the last phase of embryonic development should be adopted for estimation of the reproductive capacity of this species.
\end{abstract}

\section{INTRODUCTION}

The red banded lobster Metanephrops thomsoni (Bate, 1888) is widespread on the sandy bottom mud at a depth of around $200 \mathrm{~m}$ on the continental shelf from the western part of Japan to the Philippines across the East China Sea (Miyake, 1982). In spite of the commercial importance of the populations present in the East China Sea, previous descriptions have been limited to only embryonic (Hamasaki and Matsuura, 1987) and larval (Uchida and Dotsu, 1973) development.

The fecundity of decapod crustaceans has been estimated either from the number of oocytes in mature ovaries before spawning or from the number of eggs attached to the pleopods of females during the incubation period. In the case of the former method, however, there is a tendency to overestimate the fecundity, since a proportion of mature eggs are unspawned and remain in the ovary, being eventually absorbed, in some decapods (Matsuura et al., 1971; Farmer, 1974). Furthermore, egg loss of a high percentage occurs just after laying due to unsuccessful attachment of the eggs to the pleopods (Matsuura and Takeshita, 1985) and also during the incubation period (Brunel, 1962 ; Brunel, 1963 ; Figueiredo and Nunes, 1965 ; Perkins, 1971; Kon, 1974 ; Ito, 1976 ; Ito, 1978 ; Chapman and Ballantyne, 1980 ; Morizur et al., 1981 ; Morizur, 1981 ; Jewett et al., 1985). Thus, it is considered to be better to adopt the latter method for estimating the fecundity when the animals lay eggs on the pleopods and nurse the eggs until hatching.

This paper describes the relationship between the body size and the number of

\footnotetext{
* Present address: Tamano Branch, Japan Seafarming Association, 5-21-1 Chikko, Tamano, Okayama 706.
} 
incubated eggs of M.thomsoni in four phases of embryonic development. Estimation of egg loss in this species during the course of embryonic development was also carried out.

\section{MATERIALS AND METHODS}

Specimens used in this study were caught by bottom trawlers in the East China Sea during the period from February 1983 to November 1984 and preserved in $10 \%$ formalin. The eggs attached to the pleopods of females were carefully removed by stripping with a small pair of forceps and numbers of the eggs were counted. The carapace length from the posterior margin of the orbit to the mid dorsal edge of the carapace was measured, as the size measurement, to a precision of $0.1 \mathrm{~mm}$.

\section{Developmental Phases of Embryo}

Hamasaki and Matsuura (1987) divided the embryonic development of M.thom soni into 10 stages according to the morphological characteristics. However, as it was difficult to dissect many eggs and identify the developmental stages of the embryos according to the above-mentioned criteria, the stages were reorganized into five developmental phases (Table 1).

\section{Regression Equations for Fecundity}

The relationship between the carapace length $(\mathrm{X}, \mathrm{mm})$ and the number of eggs incubated $(\mathrm{Y})$ is expressed as $\mathrm{Y}=\mathrm{aX} \mathrm{X}^{\mathrm{b}}$, where $\mathrm{a}$ and $\mathrm{b}$ are parameters. The allometric equation shown above can be transformed into a linear regression equation, $\ln \mathrm{Y}=\ln$ $\mathrm{a}+\mathrm{b} \ln \mathrm{X}$, where $\ln$ is a natural logarithm, and we calculated the parameters using the least squares method.

The last phase $\mathrm{V}$ in Table 1 was excluded from calculation of the fecundity, because some eggs at this stage had possibly been lost due to hatching.

Table 1. Five phases in the embryonic development of Metanephrops thomsoni.

\begin{tabular}{|c|c|c|}
\hline Phase & $\begin{array}{l}\text { Stage by } \\
\text { Hamasaki and } \\
\text { Matsuura (1987) }\end{array}$ & Morphological characteristics \\
\hline I & $\mathrm{A}, \mathrm{B}, \mathrm{C}$ & $\begin{array}{l}\text { No embryonic development visible or embryonic development } \\
\text { initiated, rudiments of paired appendages present. }\end{array}$ \\
\hline II & $\mathrm{D}, \mathrm{E}$ & Biramous buds of pereopods present. \\
\hline III & $F, \quad G$ & $\begin{array}{l}\text { Eye pigmentation present in the embryo, antennular endopod } \\
\text { present, biramous pleopods present on abdominal somites II } \\
\text { to } \mathrm{V} \text {. }\end{array}$ \\
\hline IV & $\mathrm{H}, \mathrm{I}$ & $\begin{array}{l}\text { One dorsomedial spine present on each posterior edge of } \\
\text { abdominal somites II to } \mathrm{V} \text {. }\end{array}$ \\
\hline $\mathrm{V}$ & $\mathrm{J}$ & $\begin{array}{l}\text { I'lumose setae of exopods of maxillipeds and pereopods I to V } \\
\text { invaginated excluding distal end. }\end{array}$ \\
\hline
\end{tabular}




\section{RESULTS}

The relationships between the carapace length and the egg number in four different embryonic phases are presented in Fig. 1 and Table 2. We then employed analyses of covariance to inspect the common features among these four equations and

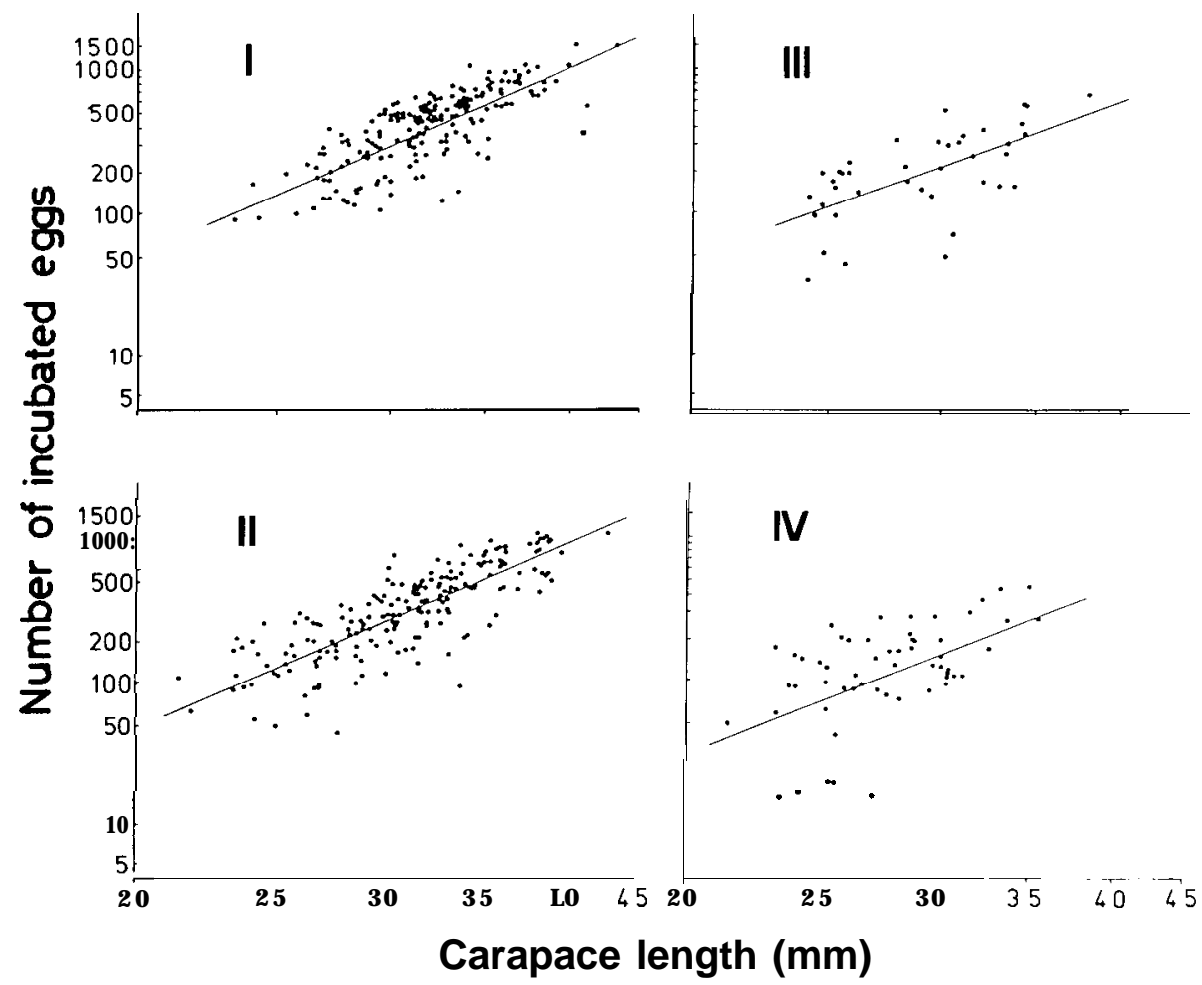

Fig. 1. Relationship between the carapace length of Metanephropsthomsoni and the number of incubated eggs in different developmental phases, I, II, III and IV.

Table 2. Results of regression analyses between the carapace length $(\mathrm{X}, \mathrm{mm})$ of Metanephrops thomsoni and the number of incubated eggs $(\mathrm{Y})$ in the regression equation: In $\mathrm{Y}=\ln \mathrm{a}+\mathrm{b}$ In $\mathrm{X}$, where $\mathrm{a}$ and $\mathrm{b}$ are parameters. $\mathrm{A}$ and $\mathrm{B}$ represents natural logarithm of $\mathrm{X}$ and $\mathrm{Y}$. * $: \mathrm{P}<0.001$.

\begin{tabular}{|c|c|c|c|c|c|c|c|c|}
\hline $\begin{array}{c}\text { Development } \\
\text { phase }\end{array}$ & $\begin{array}{l}\text { Number of } \\
\text { tal specimens } \\
\text { examined }\end{array}$ & $\begin{array}{l}\text { Correlation } \\
\text { coefficient }\end{array}$ & $\ln$ a & $\mathrm{b}$ & $\sum \mathrm{A}$ & $\sum \mathrm{B}$ & $\mathrm{CAB}$ & $\sum \mathrm{A}^{2} \sum \mathrm{B}^{2}$ \\
\hline I & 183 & $0.77^{*}$ & -8.7962 & 4.2537 & 634.1955 & 1087.9976 & 3779.7885 & $2200.0172 \quad 6534.4713$ \\
\hline II & 190 & $0.81^{*}$ & -8.8671 & 4.2443 & 653.1580 & 1087.4586 & 3753.7937 & $2248.9882 \quad 6325.6520$ \\
\hline III & 40 & $0.63^{*}$ & -6.6470 & 3.8526 & 134.8223 & 209.6881 & 708.9829 & $455.0546 \quad 1119.2163$ \\
\hline Iv & 57 & $0.55^{*}$ & -7.8563 & 3.7905 & 189.9192 & 272.0742 & 909.3216 & $633.5314 \quad 1333.9672$ \\
\hline
\end{tabular}


Table 3. Results of analyses of covariance among the four regression equations in Fig. 1 and Table 2. $-: \mathrm{P}>0.05, *: \mathrm{P}<0.05$, $* * *: \mathrm{P}<0.001$.

\begin{tabular}{lcc}
\hline Phase & Slope & Intercept \\
\hline I vs. II & & $*$ \\
I vs. III & - & $* * *$ \\
I vs. N & & $* * *$ \\
II vs. III & - & $*$ \\
II vs. IV & - & $*$ \\
III vs. IV & - & \\
\hline
\end{tabular}

Table 4. Recalculated equations showing the relationship between the carapace length (X, m) of Metanephrops thomsoni and the number of incubated eggs ( $\mathrm{Y}$ ). The percentage of egg loss was estimated from the intercepts of equations with the following formula: $100\left(1-\exp \left(a^{\prime}-a\right)\right)$, where a' and a are the intercepts of two epuations and $a^{\prime}<a$.

\begin{tabular}{cccc} 
& & \multicolumn{3}{c}{ Percent egg loss } \\
\cline { 3 - 4 } Phase & Recalculated equation & From the phase just prior to & Cumulative \\
& & & \\
I & $\ln \mathrm{Y}=4.1320 \ln \mathrm{X}-8.3742$ & 10.1 & 10.1 \\
$\mathrm{II}$ & $\ln \mathrm{Y}=4.1320 \operatorname{In} \mathrm{X}-8.4809$ & 18.4 & 26.7 \\
III & $\ln \mathrm{Y}=4.1320 \ln \mathrm{X}-8.6848$ & 26.6 & 46.2 \\
$\mathrm{~N}$ & $\ln \mathrm{Y}=4.1320 \ln \mathrm{X}-8.9941$ & &
\end{tabular}

the results are shown in Table 3 . There was no significant difference among the slopes $(\mathrm{P}>0.05)$, but the intercepts were significantly different from one another $(\mathrm{P}<0.05)$. The slopes derived from the four regression equations were not different significantly, and therefore a common slope was recalculated from the data. We obtained the new regression equations having a common slope and passing through the mean values of both the carapace length and the number of eggs in each phase (Table 4). Decrease in values of the intercept with progress of developmental phase showed that egg loss occurred during incubation, a particularly large loss occurring between phases III and IV. Total percentage of egg loss between phases I to IV of embryonic development was $46.2 \%$.

\section{DISCUSSION}

It is well known that some decapod crustaceans lose eggs which are attached to the pleopods during incubation. Brunel (1962, 1963) and Kon (1974) reported that females of the brachyuran Chionoecetes opilio might lose over half of their eggs during the incubation period. The deep-sea shrimp Pandalus borealis may incur a $27 \%$ egg loss (calculated from Ito, 1976) between egg laying and hatching. The robust shrimp Argis dentata may lose eggs at a rate of $54 \%$ (calculated from Ito, 1978) between the embryonic stage without eye pigment and more advanced stages. Matsuura and Takeshita (1985) studied egg loss during the incubation period of reared anomuran crab 
Paralithodes camtschaticus and reported that the total egg loss was $13-24 \%$ in three of the multiparous females and $53 \%$ in a primiparous one. Egg loss during incubation period has also been described in two lobsters related to the present species : $36 \%$ in Homarus americanus (Perkins, 1971) and 32-75\% in Nephrops norvegicus (Figueiredo and Nunes, 1965 ; Chapman and Ballantyne, 1980 ; Morizur et al., 1981 ; Morizur, 1981). In the present species, Metanephrops thomsoni, a $46.2 \%$ egg loss occurred during the course of embryonic development (between phases I and IV) (Table 4). All these reports indicate that egg loss is a common phenomenon among decapod crustaceans.

In general for decapod crustaceans, an accurate estimate of the fecundity cannot be obtained without examining egg numbers in relation to the course of embryonic development when egg loss occurs. The number of eggs in a developmental stage just before hatching should be obtained in order to estimate the reproductive capacity of the species. Thus, we think that the regression equation for phase IV (Table 4) is the most suitable for evaluating the reproductive capacity of $M$. thomsoni. However, all individuals used in this study were collected by bottom trawlers, and thus some of the eggs on the pleopods had probably been lost during the process of catching the lobsters and consequently the regression equations in Table 4 probably underestimate the fecundity of this species. It is therefore considered to be necessary to rear females in aquaria until they lay eggs, to determine the rate of egg loss with embryonic development and to correct the results of egg counting.

\section{ACKNOWLEDGEMENTS}

We are indebted to the following: Prof. Y. Itazawa, Kyushu University, advised and aided us ; Assoc. Prof. K.-I. Hayashi, Shimonoseki University of Fisheries, made so kind inspection of the manuscript.

We are thankful to the following who have greatly contributed toward this study : Mr. S. Murayama, the President of Murayama-suisan Inc. ; Dr. S. Mio (Present place : Far Seas Fisheries Research Laboratory), Mr. M. Tagawa and Dr. K. Takeshita, Seikai Regional Fisheries Research Laboratory ; Capt. S. Yada and the crew of the research vessel "NAGASAKI-MARU", Nagasaki University ; Mr. K. Matsukiyo and the crew of the research vessel "TOMOZURU", Nagasaki Prefectural Fisheries Experimental Station, provided us with shrimp samples.

This work was partly supported by the grant from Fisheries Agency, Ministry of Agriculture, Forestry and Fisheries, Japan.

\section{REFERENCES}

Brunel, P. 1962 Nouvelles observations sur la biologie et la biometrie du crabearaignêe Chionoecetes opilio (Fabr.). Sta. Biol. Mar. Grande-Rivière,Qué, Rapp. Annu., 1961 : 63-72

Brunel, P. 1963 Troisièmesérie d'observations sur la biologie et la biométrie du crabe-araignée Chionoecetes opilio (Fabr.). Sta. Biol. Mar. Grande-Rivière,Qué.Rapp. Annu., $1962: 91-100$

Chapman, C. J. and K. A. Ballantyne 1980 Some observations on the fecundity of Norway lobsters in Scottish waters. ICES CM, 1980/K: 25

Farmer, A. S. D. 1974 Reproduction in Nephrops norvegicus (Decapoda. Nephropidae). J.Zool., Lond.,174: 161-183

Figueiredo. M. J. and M. C. Nunes 1963 The fecundity of the Norway lobster, Nephropsnorvegicus 
(L.) in Portuguese waters. ICES CM, 1965/34:5

Hamasaki, K. and S. Matsuura 1987 Embryonic development of Metanephropsthomsoni (Bate, 1888) (Crustacea, Decapoda, Nephropidae). J.Fac. Agr., KyushuUniv., 31 (3•4): 391-403

lto, H. 1976 On the distribution and life history of a deep-sea shrimp, Pandalus borealis Kr $\phi$ yer, in the Japan Sea. Bull. Japan Sea Reg. Fish. Res. Lab., $27: 75-89$

Ito, H. 1978 The biology of the robust shrimp, Argis dentata(Rathbun), in the Japan Sea. Bull. JapanSea Reg. Fish. Res. Lab., 29: 137-145

Jewett, S. C., N. A. Sloan and D, A. Somerton 1985 Size at sexual maturity and fecundity of the fjord-dwelling golden king crab Lithodesaequispina Benedict from northern British Columbia. J.Crust. Biol., 5 (3) : 377-385

Kon, T. 1974 Fisheries biology of the Japanese tanner crab-VI. On the number of ovarian eggs and eggs held in the pleopods. Nippon Suisan Gakkaishi, $40: 46 \overline{5}-469$

Matsuura, S., K. Takeshita, H. Fujita and S. Kawasaki 1971 Reproduction and fecundity of the female king crab, Paralithodescamtschatica (Tilesius) in the waters off western Kamchatka-I. Observations of the ovarian eggs and of the spawned eggs attached to pleopods. Bull.Far Seas Fish. Res. Lab., 5: 147-160

Matsuura, S. and K. Takeshita 1985 Development and decrease in number of eggs attached to pleopods of laboratory-reared king crabs Paralithodescamtschatica (Tilesius). Proc. Int. King Crab Symp., Lowell Wakefield Fish. Symp. Ser., Univ. Alaska, Sea Grant Rep., No. 85-12:155-165

Miyake, S. 1982 Japanese Cnstacean Decupods and Slomatopods in Color, Vol. I. Macrura, Anomura and Stomatopoda, Hoikusha, Osaka

Morizur, Y., G. Conan, A. Guênolé and M. H. Omnès 1981 Féconditê de Nephropsnorvegicus dans le golfe de Gascogne. Mar.Biol., 63 : 319-324

Morizur, Y. 1981 Evaluation de la perte d'oeufs lors de l'incubation chez Nephropsnorvegicus (L.) dans la region Sud-Bretagne, France. Crustaceana, $41: 301-306$

Perkins, H. C. 1971 Egg loss during incubation from offshore northern lobsters (Decapoda :Homar idae). Fish. Bull. U. S., 69: 451-453

Uchida, T. and Y. Dotsu 1973 Collection of the T. S. Nagasaki Maru of Nagasaki University-IV. On the larval hatching and larval development of the lobster, Nephropsthomsoni.Bull.Fac. Fish., NagasakiUniv, $36: 23-35$ 